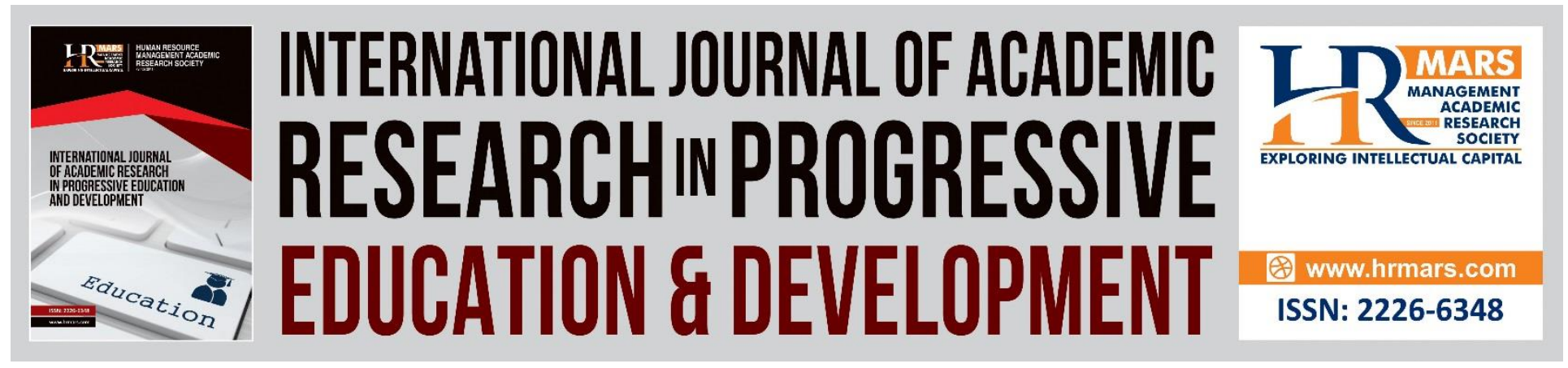

\title{
The Relationship between English Language Fluency and Learning Engagement: A Case Study among First-Year Undergraduates
}

Nur Rasyidah Othman and Kee-Man Chuah

To Link this Article: http://dx.doi.org/10.6007/IJARPED/v10-i2/9670

DOI:10.6007/IJARPED/v10-i2/9670

Received: 11 February 2021, Revised: 14 March 2021, Accepted: 17 April 2021

Published Online: 29 April 2021

In-Text Citation: (Othman \& Chuah, 2021)

To Cite this Article: Othman, N. R., \& Chuah, K.-M. (2021). The Relationship between English Language Fluency and Learning Engagement: A Case Study among First-Year Undergraduates. International Journal of Academic Research in Progressive Education and Development, 10(2), 150-162.

Copyright: (C) 2021 The Author(s)

Published by Human Resource Management Academic Research Society (www.hrmars.com)

This article is published under the Creative Commons Attribution (CC BY 4.0) license. Anyone may reproduce, distribute, translate and create derivative works of this article (for both commercial and non-commercial purposes), subject to full attribution to the original publication and authors. The full terms of this license may be seen at: http://creativecommons.org/licences/by/4.0/legalcode

Vol. 10 (2) 2021, Pg. 150 - 162

http://hrmars.com/index.php/pages/detail/IJARPED

JOURNAL HOMEPAGE

Full Terms \& Conditions of access and use can be found at http://hrmars.com/index.php/pages/detail/publication-ethics 


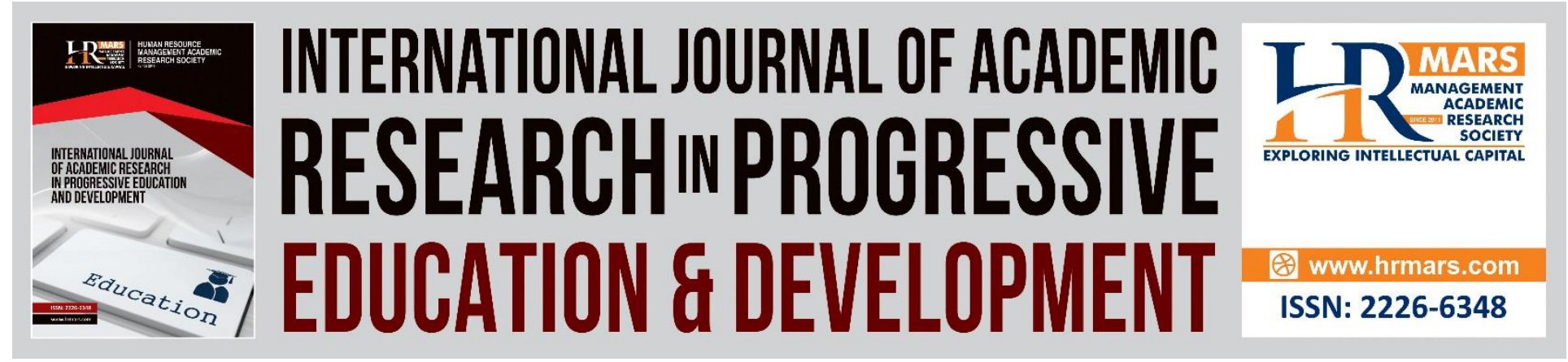

\title{
The Relationship between English Language Fluency and Learning Engagement: A Case Study among First-Year Undergraduates
}

\author{
Nur Rasyidah Othman ${ }^{1}$ and Kee-Man Chuah ${ }^{2}$ \\ ${ }^{1}$ Faculty of Cognitive Science and Human Development, Universiti Malaysia Sarawak, ${ }^{2}$ Faculty of \\ Language and Communication, Universiti Malaysia Sarawak
}

\begin{abstract}
The notion that learners with lower English language fluency tend to be less engaged in university classes still lacks further investigation. Evidence from previous studies was not conclusive and seems to suggest students with lower proficiency in the language are at risk of dropping out. This study aimed to explore the relationship between English fluency and learning engagement among first-year undergraduate students in a Malaysian university. A total of 144 students from 10 faculties participated in the study. Data were collected through a self-reported questionnaire about their English fluency, Malaysian University English Test (MUET) band and their level of engagement in the classroom. Statistical analyses revealed significant correlations in language fluency and learning engagement in which students with higher fluency were more engaged in the classroom. This study also showed students who reported higher level of perceived English language fluency and learning engagement obtained higher grades. In addition, regression analysis revealed that listening and writing skills significantly contributed to the model, which implies fluency in these two skills are more important in university settings.
\end{abstract}

Keywords: English Language Fluency, Learning Engagement, Proficieny, Muet, Classroom Instructions

Introduction

The English language is no longer limited to a linguistic and cultural phenomenon but a sociopolitical reality. English is also known as the language of information and international affairs (Andrew, 2017). In education, factors such as globalization and internalization of education and the desire to compete internationally have given rise to the growth of the English language in higher education worldwide (Gill \& Kirkpatrick, 2013). This phenomenon has led many nonEnglish speaking countries to adopt the English language in their education systems (Andrew, 2017; Gill \& Kirkpatrick, 2013). Galloway, Numajiri and Rees (2020) also reported how English has become an important criterion in the hiring of academic staff in Asian universities even in 
countries like China and Japan which are dominantly using their first language in their education system.

Malaysia is among Asian countries to implement a bilingual education system to ensure that national and international needs and challenges are balanced through language education policy (Darmi \& Albion; 2013; Gill \& Kirkpatrick, 2013). By offering both undergraduate and postgraduate programs through the medium of English, students and faculty members have the opportunity to participate in an international research community where a substantial amount of scientific work is published in English (Macaro et al., 2017). Therefore, it is essential for students to be fluent in English in order to understand complex academic materials, generate critical views, and exchange ideas with instructors and peers.

\section{Learning Engagement}

Over the last decades, research in learning engagement has been perceived as crucial in understanding student learning and development (Radloff \& Coates, 2010). The most commonly accepted view of engagement in the higher education literature emphasizes student behaviour and the practice of teaching (Kahu, 2013). The term "engagement" was understood as involvement, time and quality of effort students put into their learning (Astin, 1999; Kahu, 2013) in order to attain desired gains and academic outcomes (Barkley \& Major, 2020). It has been proven that an engaging learning environment especially in the classroom has strong associations with positive learning results (Carini, Kuh \& Klien, 2006; Kahu, 2013). Consequently, universities are now expected to provide students with a more engaging learning environment in the classroom as learning engagement is generally considered one of the best predictors of learning and personal development (Carini, Kuh \& Klein, 2006). This study was conducted to investigate the relationship between self-perceived English language fluency and learning engagement in the classroom among first-year-undergraduate students in a university in Malaysia to provide insights for administrators or faculty members who wish to promote active learning engagement among students.

Existing research on factors that lead to learning engagement classroom in higher education reveals several factors. Those factors generally fall into the following four categories: behavioural, psychological, socio-cultural, and holistic (Kahu, 2013). All these factors have been explored and examined extensively in previous research. For example, teaching practices and conation were explored as variables that can influence student learning engagement in classroom. With regards to psychological dimension, social integration, motivation, anxiety, social and emotional support within the university system were explored (Kahu, 2013). The socio-cultural dimension , which includes social and academic culture (Christie, 2008) were also examined in many empirical studies. Lastly, the holistic dimension views engagement as a dynamic continuum with different locations, for example, task, classroom, course and institution, and thus best understood by thorough qualitative research.

\section{English Fluency in Higher Education}

The four factors that were identified in the literature are applicable to all students in higher education. However, there is another factor involved when it comes to students' learning engagement in English-speaking academic environment. In this context, English is considered an 
instrument rather than a topic. Many empirical studies indicate that English fluency plays a significant role for students to complete their studies in English medium institutions, particularly students whose first language is not English (Li et al., 2010; Kahu, 2013; Martirosyan, Hwang \& Wanjohi, 2015). Mastery of English language is seen as a by-product of academic knowledge acquired in content subjects (Taguchi, 2014). Therefore, learning engagement might be affected by their English fluency, which might impact their academic performance. For example, Yang and Saumure (2006) highlighted the importance of English fluency in the socio-cultural adaptation to an English-medium academic environment. Another study conducted in foreign institutions reported that weak English fluency level was perceived as one of the reasons why students were not actively involved in class and isolated from faculty members (Wongtirat, 2010). These findings indicate that English fluency can directly affect learning engagement through its impact on other factors such as socio-cultural factor and psychological factors.

Previous studies on the English fluency among undergraduates were largely on their overall performance. Many researchers examined the relationship between language fluency and overall academic performance by using standardized tests such as IELTS (International English Language Testing System) and TOEFL (Test of English as a Foreign Language) among various groups of students in English-medium institution. The results were indirectly associated with students' learning engagement level in classroom. A study conducted at a university in Louisiana, USA (Martirosyan, Hwang \& Wanjohi, 2015) showed a statistically positive correlation between self-perceived English language fluency and grade point averages (GPAs) among 59 out of 300 students $(p=<.05)$. Similar results were reported in a study conducted at University of Wisconsin with a moderate correlation between English fluency level measured by TOEFL scores and academic performance measured by GPAs. Students with lower TOEFL scores had significantly lower grades compared to students who scored higher grades. Other studies also produce similar results on the relationship between English fluency measured by self-perceived questionnaire and overall GPA. Taguchi (2014) examined how English fluency level affects students' academic achievement by utilizing both self-reported questionnaire and standardized test such as IELTS and GPAs among 77 students in an English-medium institution. Based on the results, a statistically significant correlation $(r=.26, p=.01)$ was reported between IELTS score and GPAs, and those with low IELTS scores were more likely to score lower GPAs. In the context of Malaysia, all students are required to take the Malaysian University English Test (MUET) as part of the entry requirement. The students were graded for their proficiency in six bands, with Band 1 being the lowest while Band 6 being the highest.

Studies have also shown the need for students to have sufficient English fluency in order to be able to understand the feedback given by the instructors. Zheng, Yu and Liu (2020) investigated the individual differences among lower-proficiency students when engaging with teachers' written feedback. Dao and McDonough (2018) in their study involving Vietnamese English as a Foreign Language found that learners' proficiency levels affected peer interaction and their ability to attain feedback. While these studies indicated the effects of English fluency on students' interactions with instructors and peers, there is still a need to analyse whether their selfperceived fluency in the English language affects their overall learning engagement. In university settings where lectures, activities and assignments are all predominantly given in English, 
Vol. 10, No. 2, 2021, E-ISSN: $2226-6348$ @ 2021 HRMARS

investigating the relationship between English language fluency and engagement would be beneficial.

\section{Research Objectives}

1. To identify the relationship between students perceived English fluency level and their MUET band.

2. To examine the relationship between students perceived English fluency and their engagement in classroom.

3. To examine the relationship between learning engagement and academic performance.

\section{Research Hypotheses}

Ho1. There is no significant relationship between students perceived English proficiency level and their MUET band.

Ho2. There is no significant relationship between students' English fluency level and their learning engagement in the classroom.

Ho3. There is no significant relationship between learning engagement in the classroom and academic performance.

\section{Method}

The purpose of this study is to determine the relationship between self-perceived English language fluency and learning engagement in classroom among first year undergraduate students of a university in Malaysia, which is Universiti Malaysia Sarawak (UNIMAS). The university uses English as the main medium of instructions. Although lecturers are allowed to code-switch to the Malay language (national language), more than $80 \%$ of the course content or delivery is still in English. 5-Likert scale questionnaires were used in this study focusing on students' engagement and 4 categories of language skills; speaking, listening, reading and writing. Likert scales are designed to measure perceptions, opinions and attitudes (Burns \& Grove, 1997). The ordinal scales used in the questionnaires allowed students to express how much they agree or disagree with a particular statement. There were 5 choices of responses; strongly disagree, disagree, neutral, agree and strongly agree. Neutral indicates that the respondent either agrees or disagrees with a particular statement. The questionnaire consists of 20 items on language fluency, nine items on learning engagement, and 11 items on demographic information. The items for the questionnaires were adapted from Wanphet and Tantawy (2017) and Carini, Kuh and Klein (2006) with some items generated through the discussion with subject matter experts. A pilot study was done to check the reliability of the items. The questionnaire was then formatted in an online survey platform for data collection.

The online survey was distributed among first-year undergraduate students in UNIMAS. Random sampling method was used to obtain a more generalized set of examples. By the end of data collection period, responses from a total of 144 participants were collected. Participants were not compensated for their participation and were informed that participation was voluntary. Informed consent forms which provided information regarding the study, including the contact information of the investigator were provided at the beginning of the survey. 


\section{Results}

Students' learning engagement measured by self-reported questionnaire was the dependent variable while English language fluency was the independent variable. Descriptive statistics was used to describe the demographic characteristic of the respondents, such as gender, age, faculty, ethnicity, languages spoken and MUET Score. There were 91 (63.2\%) female and 53 (36.8\%) male students. All of the participants were first-year undergraduate students. Faculties represented in the sample were Applied and Creative Arts faculty (16.7\%), Cognitive Sciences and Human Development (13.2\%), Social Sciences and Humanities (13.2\%), Language and Communication (11.1\%), Resource Science and Technology (11.1\%), Economics and Business (9.7\%), Engineering (9\%), Computer Science and Information Technology (8.3\%), Medicine and Health Sciences (4.2\%) and Built Environment (3.5\%).

Participants were asked to indicate their MUET band. 34\% (49) of the participants scored band 3, $28.5 \%$ (41) scored band 2, 20.8\% (30) scored band 4, $12.5 \%$ (18) scored band 1, 4.2\% (6) scored band 5 and no one scored band 6 . The distribution of MUET bands is reflective of the nationwide distribution with the majority of the test takers fall into Bands 2 and 3 (Rethinasamy \& Chuah, 2011; Zaini, 2018). The overall mean score is 2.76 .

Table 1. Language most spoken at home

\begin{tabular}{lrr}
\hline \multicolumn{1}{c}{ Languages } & Frequency & Percent \\
\hline Bidayuh & 4 & 2.8 \\
Dusun & 6 & 4.2 \\
English & 2 & 1.4 \\
Foochow & 3 & 2.1 \\
Hokkien & 6 & 4.2 \\
Iban & 13 & 9.0 \\
Kadazandusun & 1 & 0.7 \\
Kayan & 1 & 0.7 \\
Kenyah & 2 & 1.4 \\
Malay & 75 & 52.1 \\
Mandarin & 17 & 11.8 \\
Melanau & 4 & 2.8 \\
Rungus & 1 & 0.7 \\
Tamil & 8 & 5.6 \\
Teochew & 1 & 0.7 \\
\hline Total & $\mathbf{1 4 4}$ & $\mathbf{1 0 0 . 0}$ \\
\hline
\end{tabular}

As shown in Table 1, participants were also asked to indicate their most commonly spoken language at home. For $52.1 \%$ of them (75 participants), Malay was the most spoken language at home, followed by Mandarin (11.8\%), Iban (9\%), Tamil (5.6\%), Hokkien (4.2\%), Dusun (4.8\%), Melanau (2.8\%), Foochow (2.1\%), English (1.4\%), Kenyah (1.4\%), Kayan (0.7\%), Rungus (0.7\%) and Teochew (0.7\%). Only two respondents used English language at home, and their perceived 


\section{INTERNATIONAL JOURNAL OF ACADEMIC RESEARCH IN PROGRESSIVE EDUCATION AND DEVELOPMENT}

Vol. 10, No. 2, 2021, E-ISSN: 2226-6348 @ 2021 HRMARS

English language fluency, MUET band and academic performance (CGPA) are higher compared to other respondents.

Table 2. Frequency of English used by lecturers in classroom and English use in classroom

\begin{tabular}{llrr}
\hline & N & Mean & Std. Deviation \\
\hline English used by lecturers & 144 & 4.24 & .709 \\
English use in classroom & 144 & 4.06 & .768 \\
\hline
\end{tabular}

The mean scores for both variables in Table 2 were high with the value of 4.24 and 4.06 respectively. It shows that English language is often used as a medium of instruction in the classroom across fields, not just in sciences.

\section{Results from Hypothesis Testing}

The collected data on items concerning English fluency learning engagement were then further analyzed through correlation statistics.

Ho1: There is no significant relationship between students perceived English fluency level and their MUET band.

Table 3. MUET Band and Perceived English Language Fluency

\begin{tabular}{|c|c|c|c|c|}
\hline & & & MUET Band & $\begin{array}{c}\text { Perceived } \\
\text { English Fluency }\end{array}$ \\
\hline \multirow[t]{7}{*}{ Spearman's rho } & MUET Band & Correlation & 1.000 & $.799^{* *}$ \\
\hline & & Coefficient & & \\
\hline & & Sig. (1-tailed) & . & .000 \\
\hline & & $\mathrm{N}$ & 144 & 144 \\
\hline & $\begin{array}{l}\text { Perceived English } \\
\text { Fluency }\end{array}$ & $\begin{array}{l}\text { Correlation } \\
\text { Coefficient }\end{array}$ & $.799^{* *}$ & 1.000 \\
\hline & & Sig. (1-tailed) & .000 & • \\
\hline & & $\mathrm{N}$ & 144 & 144 \\
\hline
\end{tabular}

**. Correlation is significant at the 0.01 level (1-tailed).

The correlation between MUET Band and perceived English language fluency was significant with strong positive correlation $(r=0799, n=144, p<.001)$. This means that their perceived English language fluency is in accordance with their MUET bands, and therefore, the null hypothesis is rejected.

Ho2: There is no significant relationship between students' English fluency level and their learning engagement in classroom. 
INTERNATIONAL JOURNAL OF ACADEMIC RESEARCH IN PROGRESSIVE EDUCATION AND

DEVELOPMENT

Vol. 10, No. 2, 2021, E-ISSN: 2226-6348 @ 2021 HRMARS

Table 4. The relationship between perceived English language fluency and learning engagement in classroom.

\begin{tabular}{|c|c|c|c|c|}
\hline & & & $\begin{array}{l}\text { Perceived } \\
\text { English } \\
\text { Fluency } \\
\end{array}$ & $\begin{array}{c}\text { Learning } \\
\text { Engagement in } \\
\text { Classroom }\end{array}$ \\
\hline \multirow[t]{6}{*}{ Spearman's rho } & $\begin{array}{l}\text { Perceived English } \\
\text { Fluency }\end{array}$ & $\begin{array}{l}\text { Correlation } \\
\text { Coefficient }\end{array}$ & 1.000 & $.669^{* *}$ \\
\hline & & Sig. (1-tailed) & . & .000 \\
\hline & & $\mathrm{N}$ & 144 & 144 \\
\hline & $\begin{array}{l}\text { Learning Engagement } \\
\text { in Classroom }\end{array}$ & $\begin{array}{l}\text { Correlation } \\
\text { Coefficient }\end{array}$ & $.669^{* *}$ & 1.000 \\
\hline & & Sig. (1-tailed) & .000 & \\
\hline & & $\mathrm{N}$ & 144 & 144 \\
\hline
\end{tabular}

**. Correlation is significant at the 0.01 level (1-tailed).

The significant correlation coefficient value confirmed that there was a strong positive correlation between perceived English fluency level and learning engagement in classroom among students $(r=.67, n=144, p<.001)$. This means that English fluency level did affect students' engagement in classroom. Therefore, the null hypothesis showing no significant relationship between students' English fluency level and their engagement in classroom was rejected.

Ho3: There is no significant relationship between learning engagement in classroom and academic performance.

Table 5. The relationship between learning engagement in classroom and academic performance.

\begin{tabular}{|c|c|c|c|c|}
\hline & & & $\begin{array}{l}\text { Learning } \\
\text { Engagement in } \\
\text { the Classroom }\end{array}$ & CGPA \\
\hline \multirow[t]{7}{*}{ Spearman's rho } & Learning & Correlation & 1.000 & $.540^{* *}$ \\
\hline & Engagement in & Coefficient & & \\
\hline & Classroom & Sig. (1-tailed) & . & .000 \\
\hline & & $\mathrm{N}$ & 144 & 144 \\
\hline & CGPA & $\begin{array}{l}\text { Correlation } \\
\text { Coefficient }\end{array}$ & $.540^{* *}$ & 1.000 \\
\hline & & Sig. (1-tailed) & .000 & . \\
\hline & & $\mathrm{N}$ & 144 & 144 \\
\hline
\end{tabular}

**. Correlation is significant at the 0.01 level (1-tailed).

Table 5 revealed a significant but moderate positive correlation between learning engagement in classroom and academic performance among students $(r=.54, n=144, p<.001)$. The result 
Vol. 10, No. 2, 2021, E-ISSN: $2226-6348$ @ 2021 HRMARS

showed that learning engagement does contribute to students' academic achievement. Therefore, null hypothesis was rejected.

A standard multiple regression was utilized to further examine the relationship between English language fluency and learning engagement in the classroom among students. Self-perceived learning engagement in the classroom was the dependent variable, while self-perceived English language fluency consists of speaking, listening, reading, and writing were the independent variables. The independent variable explains $48.6 \%$ of the variance in learning engagement, which is significant, as indicated by F-value, $F(2,12)=34.081, p<0.0005$. A summary of regression coefficients presented in Table 6 indicated that two out of four variables, which are listening $(p=$ $.002)$ and writing $(p=.04)$ significantly contribute to the model.

Table 6. Multiple regression analysis

\begin{tabular}{|c|c|c|c|c|c|c|}
\hline \multirow{2}{*}{\multicolumn{2}{|c|}{ Model }} & \multicolumn{2}{|c|}{$\begin{array}{c}\text { Unstandardized } \\
\text { Coefficients }\end{array}$} & \multirow{2}{*}{$\begin{array}{c}\begin{array}{c}\text { Standardized } \\
\text { Coefficients }\end{array} \\
\text { Beta }\end{array}$} & \multirow[b]{2}{*}{$\mathbf{t}$} & \multirow[b]{2}{*}{ Sig. } \\
\hline & & $B$ & Std. Error & & & \\
\hline \multirow[t]{5}{*}{1} & (Constant) & 1.384 & .219 & & 6.320 & .000 \\
\hline & Speaking & -.079 & .113 & -.107 & -.697 & .487 \\
\hline & Listening & .370 & .118 & .368 & 3.135 & .002 \\
\hline & Reading & .050 & .114 & .076 & .441 & .660 \\
\hline & Writing & .257 & .124 & .389 & 2.073 & .040 \\
\hline
\end{tabular}

a. Dependent Variable: Learning Engagement

\section{Discussion}

The results from the survey of 144 first-year undergraduate students at UNIMAS supported the general conception on the importance of English language fluency in higher education settings. The statistical outputs showed a significant correlation between perceived English language fluency and learning engagement in the classroom. There was also a significant correlation between learning engagement in the classroom with academic performance. In order to ensure that students perceived English language fluency is in accordance with their MUET bands, a correlation analysis was conducted, and the result was positively significant. Multiple regression analysis revealed that listening and writing skills significantly contribute to learning engagement in the classroom.

The expected hypothesis was that English fluency does impact learning engagement in the classroom. In a recent study done by Ghenghesh (2014), it was found that student's proficiency in English was significantly correlated with their overall academic achievement. Specifically, the higher the English proficiency of students on entry to the university, the better they performed in both degree courses and language skills. The same study also found that academic achievement was shown to have a direct relationship with learning engagement.

Since English is a medium of instruction at UNIMAS, students must be able to speak, listen, read and write at a level appropriate to their studies in order to be able to engage actively. Previous studies (Maleki \& Zangani, 2007; Roche \& Harrington, 2013) also found a significant relationship 
between English fluency and learning engagement. Although a number of studies emphasize the English fluency level as measured by standardized tests such as TOEFL, IELTS and GPAs, there are also studies that suggest that standardized tests might not be a good predictor of academic success for students. For example, in a study conducted by Krausz et al. (2005), the researchers found that TOEFL scores were not associated with students' actual academic difficulties. In a meta-analysis of 22 studies on the relationship between English fluency and learning engagement in classroom of students in English-medium institutions, the result showed that TOEFL score had a small predictive ability on students' learning engagement and overall academic achievement (Wongtrirat, 2010). The findings were contradictory, implying that English fluency measured solely by these standardized tests cannot be a reliable predictor of students' learning engagement. In addition, Fox (2014) noted that language tests fail to measure other contributing factors such as the social network of support, financial security, time availability and academic adjustment that might affect students' engagement. Other researchers also indicated other contributing factors such as inadequate background knowledge, poor study skills, difficulty in coursework, motivation, and experiences (Krausz et al., 2005; Kahu, 2013; Martirosyan, Hwang \& Wanjohi, 2015; Taguchi, 2014). Therefore, additional investigations are needed to explore other constructs in measuring English fluency and how it affects students' engagement level. On the other hand, studies that depended on self-perceived questionnaire only may be exposed to invalid answers or the respondents may not answer truthfully. The current study utilized a standardized English test (MUET) to further ensure the validity of collected data.

The result from multiple regression analysis revealed an interesting finding. Contrary to widely accepted perception where speaking and reading skills are considered important to actively engage in learning (Martirosyan et al., 2015; Wanphet \& Tantawy, 2017), the result revealed that listening and writing skills significantly contribute to learning engagement in classroom. Martirosyan et al. (2015) found that international students with good speaking and reading skills performed better in academics. However, the study was conducted in Louisiana, United States, where international students were considered to have mastered at least a basic level of English fluency. While in UNIMAS, some of the respondents scored Band 1 in the MUET test, which means they have a very limited understanding of the language and context and hardly able to use or work with the language.

\section{Conclusion and Implications}

All in all, it can be concluded that English fluency is a determinant of learning engagement in the classroom for students studying in an institution that adopts the English language as a medium of instruction. The findings of the current study revealed that the higher the English language fluency of students, the higher their learning engagement in the classroom. Specifically, students' ability in listening and writing are deemed to be more important in classroom engagement since most of the class hours are filled with lectures and written tasks. Therefore, it is recommended that higher institutions help students to improve their English fluency skills by providing appropriate programmes to assist students with low fluency. As shown by the results of this study, such decision will have important implications for instruction and learning engagement. It is also important to note some of the limitations of this study. Firstly, it was limited to one 
institution. It is recommended for further studies to include more than one institution in order to have a larger sample size. Secondly, this study was limited to a quantitative survey. Future research could employ a mixed-methods approach in order to obtain more comprehensive information on self-perceived English fluency level and learning engagement in classroom among students.

The study has provided valuable insights on the linkage between students' fluency in English and their engagement in classroom activities. It has contributed in terms of understanding the impact of students fluency level beyond the performance variable that has been investigated in previous studies. By knowing that English fluency has an effect on students level of engagement, instructors could be more alert and ensure that students who are weak in the language would obtain necessary help. It is also worthy to note that English has become an important medium of instruction in higher education across Asia and students have to improve their proficiency and fluency in the language so as to ensure they are able to be more involved and participative in the classroom activities.

\section{References}

Andrew, A. (2017). English medium instructions on English language proficiency. Asian Research Journal of Arts \& Social Sciences, 1-10.

Astin, A. W. (1999). Student involvement: A developmental theory for higher education. Journal of College Student Development, 40(5), 518-529.

Barkley, E. F., \& Major, C. H. (2020). Student engagement techniques: A handbook for college faculty. New York: John Wiley \& Sons.

Burns, N., \& Groves, K. (1997). Practice of nursing research. Philadelphia, PA: WB Saunders company.

Demetriou, C., Ozer, B. U., \& Essau, C. A. (2015). Self-reported questionnaires. The Encyclopedia of Clinical Psychology, 1-6. https://doi.org/10.1002/9781118625392.wbecp507

Darmi, R., \& Albion, P. (2013). English language in the Malaysian education system: its existence and implications. Proceedings of the 3rd Malaysian Postgraduate Conference (MPC 2013), 175-183. Retrieved from http://eprints.usq.edu.au/id/eprint/24021

Dao, P., \& McDonough, K. (2018). Effect of proficiency on Vietnamese EFL learners' engagement in peer interaction. International Journal of Educational Research, 88, 60-72.

Carini, R. M., Kuh, G. D., \& Klein, S. P. (2006). Student Engagement and Student Learning: Testing the Linkages. Research in Higher Education, 47(1), 1-32. https://doi.org/10.1007/s11162005-8150-9

Chuah, K. M. (2014). Word's up with WhatsApp: the use of instant messaging in consciousnessraising of academic vocabulary. Paper presented at the 23rd MELTA and 12th Asia TEFL International Conference (pp. 28-30).

Christie, H., Tett, L., Cree, V. E., Hounsell, J., \& Mccune, V. (2008). A real rollercoaster of confidence and emotions: Learning to be a university student. Studies in Higher Education, 33, 567-81. Coates, H. (2010). Development of the Australasian survey of student engagement (AUSSE). Higher Education, 60, 1-17. 
INTERNATIONAL JOURNAL OF ACADEMIC RESEARCH IN PROGRESSIVE EDUCATION AND

DEVELOPMENT

Vol. 10, No. 2, 2021, E-ISSN: $2226-6348$ @ 2021 HRMARS

Ghenghesh, P. (2014). The relationship between English language proficiency and academic performance of university students-Should academic institutions really be concerned? International Journal of Applied Linguistics \& English Literature, 4(2).https://doi.org/10.7575/aiac.ijalel.v.4n.2p.91.

Galloway, N., Numajiri, T., \& Rees, N. (2020). The 'internationalisation', or 'Englishisation', of higher education in East Asia. Higher Education, 80(3), 395-414.

Gill, S. K., \& Kirkpatrick, A. (2013). English in Asian and European higher education. The Encyclopedia of Applied Linguistics. https://doi.org/10.1002/9781405198431.wbea 10383

Kahu, E. R. (2011). Framing student engagement in higher education. Studies in Higher Education, 38(5), 758-773.

Li, G., Chen, W., \& Duanmu, J-L. (2010). Determinants of international students' academic performance: A comparison between Chinese and other international students. Journal of Studies in International Education, 14, 389-405. doi:10. 1177/1028315309331490

Macaro, E., Curle, S., Pun, J., An, J., \& Dearden, J. (2018). A systematic review of English medium instruction in higher education. Language Teaching, 51(1), 36-76.

Maleki, A., \& Zangani, E. (2007). A survey on the relationship between English language proficiency and the academic achievement of Iranian EFL students. Asian EFL Journal, 9(1), 86-96.

Martirosyan, N. M., Hwang, E., \& Wanjohi, R. (2015). Impact of English Proficiency on Academic Performance of International Students. Journal of International Students, 5(1), 60-71. Retrieved from https://www.ojed.org/index.php/jis/article/view/443

Radloff, A., \& Coates, H. (2010). Doing More for Learning: Enhancing Engagement and Outcomes: Australasian Survey of Student Engagement: Australasian Student Engagement Report.

Rethinasamy, S., \& Chuah, K. M. (2011). The Malaysian University English Test (MUET) and its use for placement purposes: A predictive validity study. Electronic Journal of Foreign Language Teaching, 8(2), 234-245.

Roche, T., \& Harrington, M. (2013). Recognition vocabulary knowledge as a predictor of academic performance in an English as a foreign language setting. Language Testing in Asia, 3(1), 113.

Taguchi, N. (2014). English-medium education in the global society. International Review of Applied Linguistics in Language Teaching, 52(2). https://doi.org/10.1515/iral-2014-0004

Wongtirat, R. (2010). English language proficiency and academic achievement of international students: A meta-analysis. Retrieved from ProQuest Dissertations and Theses database. (UMI No. 1434728)

Yang, R., P-J., Noels, K. A., \& Saumure, K. D. (2006). Multiple routes to cross-cultural adaptation for international students: Mapping the paths between self-construals, English language confidence, and adjustment. International Journal of Intercultural Relations, 30, 487-506. https://doi.org/10.1016/j.ijintrel.2005.11.010

Zaini, N. (2018). The Relationship between Multiple Intelligence on the Performance of Arts Stream Students in Linear and Non-Linear MUET Reading Component. International Journal of Academic Research in Progressive Education and Development, 7(4), 80-94. http://dx.doi.org/10.6007/ IJARPED/v7-i4/4837 


\section{INTERNATIONAL JOURNAL OF ACADEMIC RESEARCH IN PROGRESSIVE EDUCATION AND}

DEVELOPMENT

Vol. 10, No. 2, 2021, E-ISSN: 2226-6348 @ 2021 HRMARS

Zheng, Y., Yu, S., \& Liu, Z. (2020). Understanding individual differences in lower-proficiency students' engagement with teacher written corrective feedback. Teaching in Higher Education, 1-21. 